\title{
A NORIC-PANNONIAN BELT CLASP FROM THE POD ROHAČKOU SETTLEMENT, PLOŠTÍN, LIPTOVSKÝ MIKULÁŠ DISTRICT
}

\author{
M A R T I N F U R A N
}

\begin{abstract}
In recent years, we have been monitoring a number of new archaeological finds from the Liptov Basin, either from well-known or newly discovered archaeological sites. The well-known archeological site Pod Rohačkou is no exception. Together with the Rohačka fortified settlement and the surrounding fortifications Bodová, Končistý, Ilanovská poludnica and Demänovská hora, they form a micro-region with traces of settlement from the Bronze Age to the Middle Ages. In 2018, the Žilina Regional Monuments Board began a systematic archaeological research of the archaeological site Pod Rohačkou under the Rohačka fortifications. During the six seasons so far, a set of more than 350 items from various time periods from prehistory to modern times has been obtained. Based on previous knowledge, the polycuctural character of the Pod Rohačkou site can be defined as the period from the Bronze Age to the Roman period, with the most significant representation of the Roman phase of the Púchov culture. It is this period that includes finding no. 67, which is an incomplete belt clasp, so-called Noric-Pannonian type and is the subject of this short contribution.
\end{abstract}

Keywords: Slovakia, Liptov region, Early Roman Period, Púchov culture, Noric-Pannonian belt clasp.

In recent years, we observe an increasing number of new archaeological finds from either newly discovered or already known sites in the Liptov Region (e.g. Furman 2019; 2020; Lofajová/Furman 2019). The well-known archaeological site Pod Rohačkou is no exception. Together with the Rohačka hillfort and neighbouring fortificatons - such as Bodová, Končistý, Il'anovská poludnica and Demänovská hora - the sites form a micro-region with traces of settlement ranging from the Bronze Age to the Middle Ages (Furman 2016). A complex review of research on this exceptional region can be found in a published article by Benediková et al. (2019).

Thus, there is no need to discuss it in detail in this brief paper. The name of Karol Pieta will forever be associated with the discovery of many of the sites, not only those abovementioned. Longterm systematic research on the now well-known site Havránok in Liptovská Mara provided foundations for his seminal works on early historic times, the Púchov Culture period in North-Western Slovakia (Pieta 1982). Over the next almost 40 years, Karol Pieta gathered new knowledge about other, mainly highland sites and contributed to the reevaluation of many previous views on the scarcity of the settlement in the Liptov Region. The current brief paper concerning another find, a NoricPannonian belt clasp from Liptov, contributes to the current knowledge about the occurrence of this magnificent belt set - the so-called NoricPannonian type.
In 2018, Regional Monuments Board Žilina started systematic archaeological research of the open settlement below the Rohačka fortifications. The fortifications were known already in the $18^{\text {th }}$ c. when Matthias Bel $(2014,217)$ mentioned them for the first time. A metal detection survey was initiated after a collection of archaeological finds - mostly bronze clasps - was handed over to the archaeologists (see Brezñanová/Furman 2019). By the end of 2020, during the six research seasons, we obtained a set of over 350 items dating back to various periods, from prehistory to modern times. In the first stage, the research aims at documenting the scope and character of the settlement as well as its chronological frames. Since the site is now exploited as arable land, systematic metal detection is possible twice a year - in spring or autumn, following ploughing or sowing. Documenting relevant archaeological finds with an accuracy up to a decimetre using a GPS tool - LT $500 \mathrm{~T}$ - allows us to determine the scope of the settlement in the area relatively well.

Based on the recent findings, the settlement Pod Rohačkou could be attributed to the period between the Bronze Age and the Roman Period, with considerable traces of the Roman phase of the Púchov Culture. Find no. 67 - the fragment of the Noric-Pannonian belt clasp - comes from that period. The clasp was found in the southwestern part of the site at a depth of $5 \mathrm{~cm}$, during an autumn metal detection survey in 2018 (Fig. 1). 


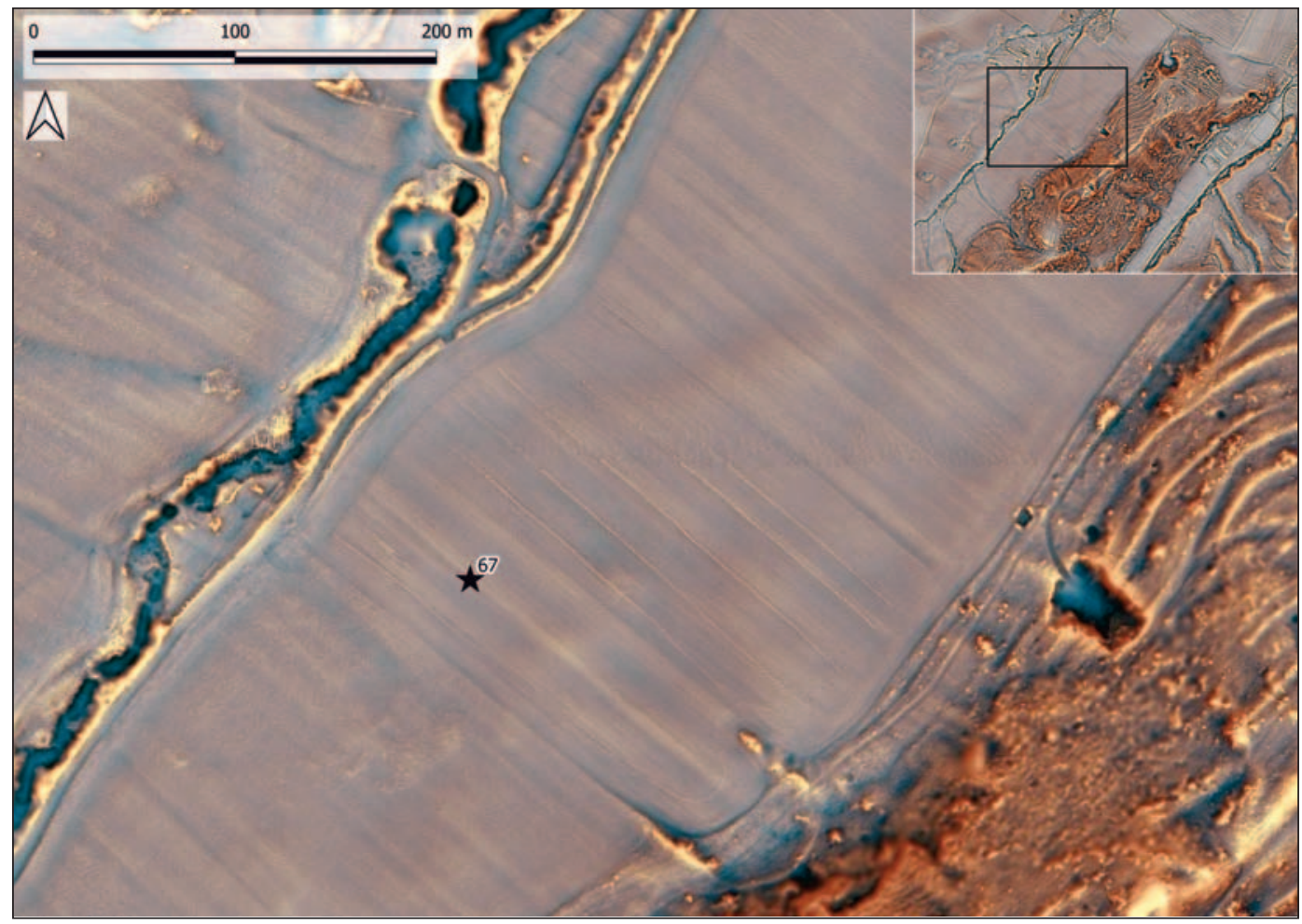

Fig. 1. Ploštín. Lidar image of the open settlement Pod Rohačkou with the spot where the Noric-Pannonian belt clasp was found (source ÚGKK SR; elaborated by T. Lieskovský and J. Zachar).

\section{DESCRIPTION AND EVALUATION OF THE FIND}

Unfortunately, this rectangular clasp with a bent frame and two thorns found on the settlement Pod Rohačkou is damaged. It lacks one side and the back of the clasp is bent (Fig. 2). Nevertheless, based on characteristic features, it was possible to reliably determine its type as G2b (Garbsch 1965, 81, fig. 43). The front, concave side - a bit narrower than the backside - has two undecorated fastening thorns. The preserved shorter concave side is framed by two gentle ribs. J. Garbsch $(1965,81,82)$ recognised this type based on single finds from Magdelensberg and Sisak and determined the type chronology based on similar forms known from assemblages to the period between the reign of Tiberius (14-37 AD) and the first decades of the $2^{\text {nd }} c$. AD. Most likely, the clasp was about $49 \mathrm{~mm}$ long and $28 \mathrm{~mm}$ wide - which is consistent with the finds from Magdelensberg and Sisak. The damaged item from the settlement Pod Rohačkou weighs 11,806 g.

From North-Western Slovakia, there are NoricPannonian clasps both with one (types of the G1 group) and two fastening thorns (types of the G2 group). K. Pieta investigated such clasps in numerous works (Pieta 1982; 2014; 2019). In Northern Slovakia, clasps of those types were found

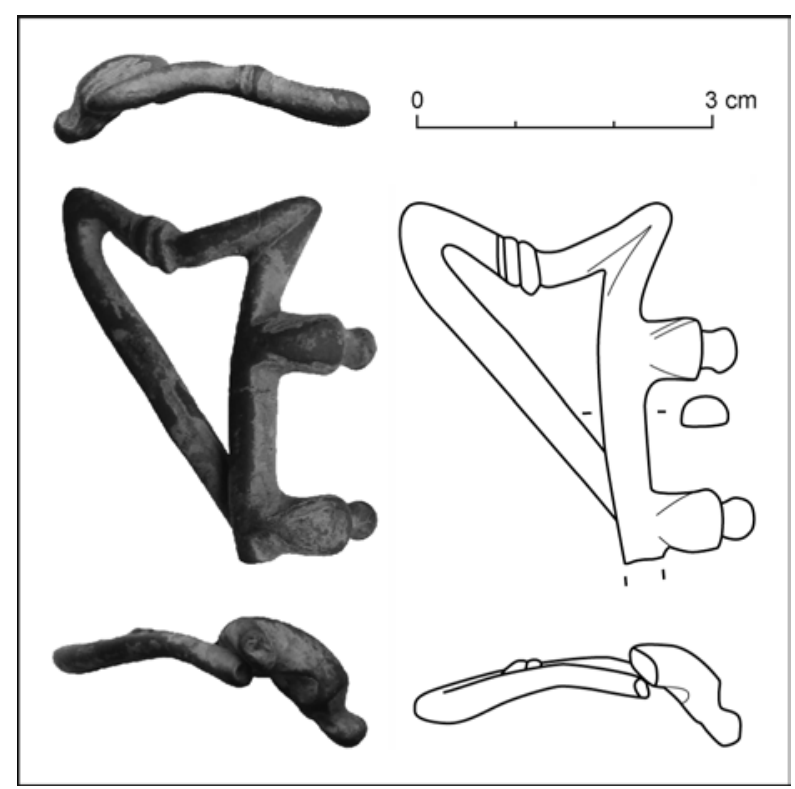

Fig. 2. Ploštín. Noric-Pannonian belt clasp from the settlement Pod Rohačkou (elaborated by M. Furman).

in Early Roman layers of the decline horizon of the Púchov Culture, on hillforts in Podskalie and Vyšný Kubín (Pieta 2014, 149) but also as parts of female Noric-Pannonian belt sets (Bytča-Hrabové: Pieta 2019, 245 f.). According to P. Euczakiewicz and 
M. Schönfelder $(2008,162)$, clasps can be found in both male and female graves and thus are not related to gender.

The closest analogies to the clasp from the settlement Pod Rohačkou can be found in a skeletal double grave in Bytča-Hrabové (Pieta 2019, 246, fig. 6: $28 \mathrm{~d}$ ). Both items have similarly framed shorter edges and fastening thorns resemble duck heads without engraved ornaments. Unlike similar clasps from Blatica or Bytča-Hrabové, thorns of the find from Pod Rohačkou are inwardly bent. The feature is not a result of secondary damages to the item. Similar types of Noric-Pannonian clasps with two thorns are known from Blatnica and Košeca-Nozdrovice (Pieta 2019, 272, fig. 27: 5, 6). The equipment from grave 1 from Bytča - according to an anthropological report by J. Jakab $(2011,117)$ of a 30-40-year-old woman - contains also a pair of the Almgren 67 fibulas, bronze rivets and boat-like plaques with a pair of rivets on each side. All these types of items were present on the settlement Pod Rohačkou. They were scattered throughout the site with a considerable concentration in the south-eastern part of the area. The well-documented presence of profiled belt-ends, boat-like plaques and various small shields indicates that inhabitants of the settlement agglomeration Pod Rohačkou wore belt sets of the so-called Noric-Pannonian type.

Thanks to the preliminary metal detection surveys on the arable land, the open settlement Pod Rohačkou provides an abundant database of archaeological finds from the period between the Bronze Age and the Roman phase of the Púchov Culture, the latter being also most prominent on the site. In terms of the finds, the settlement Pod Rohačkou resembles numerous settlements in the Liptov (Liptovská Mara-Havránok, Likavka-Predné hony) and Turiec (Blatnica-Rovná, Folkušová-Necpaly). This, in turn, corroborates the view that, in prehistoric times and early historic periods, there were intense mutual contacts between the regions and at the turn of the eras, both belonged to one cultural milieu. The clasp discussed in this paper provides yet another confirmation of this hypothesis.

\section{BIBLIOGR APHY}

Bel 2014 - M. Bel: Liptovská stolica. Čadca 2014.

Benediková et al. 2019 - L. Benediková/M. Furman/Z. Bielichová/J. Mihályová/J. Tirpák: Čo (staro)nového pod Rohačkou? In: L. Benediková/G. Březinová/E. Horváthová/S. Stegmann-Rajtár (eds.): Fragmenty času. Venované Elene Miroššayovej k 70. narodeninám. Študijné zvesti AÚ SAV - Supplementum 1. Nitra 2019, 51-88. DOI: https://doi.org/10.31577/szausav.2019.suppl.1.2

BrezňanoválFurman 2019 - G. Brezňanová/M. Furman: Súbor nálezov zo sídliska v Ploštíne pod hradiskom Rohačka. Príspevok je venovaný prof. Jozefovi Bujnovi $\mathrm{k}$ jeho životnému jubileu 70. rokov. Monument revue 2, 2019, 12-22.

Furman 2016 - M. Furman: Opevnenia na Liptove. Refúgiá, hradiská a hrádky od praveku po stredovek. Źilina 2016.

Furman 2019 - M. Furman: Tri nové archeologické náleziská na Liptove zistené leteckým laserovým skenovaním. Monument revue 2, 2019, 2-5.

Furman 2020 - M. Furman: Nové objavy v Žilinskom kraji I. Archeologickéaktivity Krajského pamiatkového úradu Žilina v rokoch 2014-2018. Žilina 2020.

Garbsch 1965 - J. Garbsch: Die Norisch-pannonische Frauentracht im 1. und 2. Jahrhundert. Müncher Beiträge zur Vor- und Frühgeschichte 11. München 1965.
Jakab 2011 - J. Jakab: Kostry zo ženského dvojhrobu púchovskej kultúry v Bytči. AVANS 2008, 2011, 116-118.

Lofajová Danielová/Furman 2019 - B. Lofajová Danielová/ M. Furman (eds.): Výsledky nových archeologických výskumov na strednom Slovensku II. a III. Zborník príspevkov z 2. a 3. ročníka konferencie archeológov pôsobiacich voblasti stredného Slovenska. Banská Bystrica 2017 - Oravský Podzámok 2018. Dolný Kubín - Bratislava 2019.

Łuczkiewicz/Schönfelder 2008 - P. Łuczkiewicz/M. Schönfelder: Untersuchungen zur Ausstattung eines späteisenzeitlichen Reiterkriegers aus den südlichen Karpatenoder Balkanraum. Jahrbuch des Römisch-Germanischen Zentralmuseums 55, 2008, 159-209. DOI: https://doi.org/10.11588/jrgzm.2008.1.16837

Pieta 1982 - K. Pieta: Die Púchov-Kultur. Archaeologica Slovaca Monographiae. Studia 1. Nitra 1982.

Pieta 2014 - K. Pieta: Hradiská vo Folkušovej-Necpaloch a Blatnici. Juhovýchodné prvky v púchovskej kultúre. Slovenská archeológia 62, 2014, 125-165.

Pieta 2019 - K. Pieta: Early Roman Period Burials of Púchov Cuture: Buried Natives or Offered Foreigners? Slovenská archeológia 67, 2019, 241-286.

DOI: https://doi.org/10.31577/slovarch.2019.67.8

Mgr. Martin Furman, PhD

Krajský pamiatkový úrad Žilina

Mariánske námestie 19

SK - 01001 Žilina

martin.furman.za@gmail.com 
